\title{
AVIGNON ABOUNDING IN NEW PROJECTS
}

\author{
MILOŠ MISTRÍK
}

Institute of Theatre and Film Research,

Art Research Centre of the Slovak Academy of Sciences, Bratislava

\begin{abstract}
In the text, which is a reflection on the Festival d'Avignon 2019, the author names new trends in dramaturgy, direction, and stage design. Among the most distinct themes in the focus of theatre makers were resistance to totalitarian regimes, the struggle for human freedom, or a very hot topic of a modern Odyssey of people banished from their homes. In addition to artistic issues, the text also reflects on the concerns associated with designing and funding theatre productions and on a gradual loss of acclaimed, widely recognised theatre personalities.

Key words: Festival d'Avignon 2019, contemporary French theatre, Olivier Py
\end{abstract}

One of the most prominent European theatre festivals is held in Avignon every summer. It is a display of not only French theatre but also of other, often exotic cultures. During its 73rd edition (4 - 23 July 2019), theatre performers from Brazil, China, Burkina Faso, Egypt, Russia, Switzerland, Great Britain, and from other countries made their appearances. Some basic figures will give us an idea of the scope of the festival. In the main programme, 43 scenic and multimedia productions presented in 282 performances were put up for the viewers. In three weeks, they were frequented by 138,000 spectators. On the other side of the theatre ramp, 1,700 artists, technicians, and organisational staff were involved in putting the programme together. However, it should be noted that the figures only relate to the main (the "In") festival in Avignon and, in parallel, as every year, also the Festival OFF d'Avignon is held, which is less formal, but much more impressive when it comes to figures $(5,920$ performing artists featuring in 1,592 performances). The Festival d'Avignon is a nationwide holiday frequented by a large number of domestic and foreign tourists, theatre and culture lovers. Many do not even buy tickets for shows, they are perfectly happy to stroll through the streets of the city and to stop over at every corner and enjoy the performances of various comedians, improvisers, clowns, jugglers, singers, and dancers. According to the statistics, there are hundreds of thousands of such visitors, who for three weeks would keep streaming through the streets of the city centre with promo posters put up everywhere.

However, the massive scale of the event accounts for the fact that in the huge offer, rather than making their presence felt, performing theatre companies fail to be noticed. An excessive offer overshadows them indirectly. This applies in particular to drama ensembles included in the Festival OFF d'Avignon, although among its prime functions is its market, commercial role. Theatre companies and troupes of mostly young people come here to make an appearance, to perform, and to get invitations to the next season. They promote their performances in the streets, and once the viewer is intrigued, they would then perform in theatre halls. We must not 
think that only experimenting and the avant-garde predominate at the young Festival OFF d'Avignon. Participating theatres strive to assert themselves mainly in the commercial field. They offer operettas and musicals and, by way of example, they would often perform George Feydeau and similar authors, causerie or lustful plays. Drama ensembles that are included in the main, official part, are better off: they are not lost in the programme, some are centrally funded, and the main interest of viewers, experts, and the media is focused on them.

But even this is quite complex. Due to ever-changing cultural subsidies, there is an increase in the number of productions that are put on stage only or mainly thanks to one-off subsidies based on project competitions. The classical budget repertory theatres with a unique dramaturgical line and with their own pool of artistic collaborators and viewers, had to change their practices. Ad hoc teams are created from wider databases, ensembles are set up on a case-by-case basis, the co-productions of several, or even many theatres, are forged to stage a theatre production, which then rotates on the stages of all co-producers throughout the entire season. Obviously, it is hard to tell which co-producer's poetics the production refers to. Long gone are the times when the drama ensembles of Jean Vilar, Roger Planchon, Jean-Louis Barrault epitomised a kind of artistic and poetological certainty. After all, there has never been an excess of permanent ensembles in France, just like we are used to in Slovakia. The tradition of one-off projects is very much alive there. For the sake of exhaustiveness, it should be noted that such project productions are created not just during a regular theatre season. The Avignon Festival in its capacity of a producer, also offers the possibility to apply for project funding. Hence, the festival is not only a passive platform for the presentation of finished works, but it is also a sparkplug and inspirer of theatre production. The productions created thanks to festival subsidies naturally come to the centre of attention and are expected to be at their best. In 2019, Architecture [Architecture] by Pascal Rambert, L'Amour vainqueur [Love Triumphant] by Olivier Py, L'Amitié [Friendship] by Irène Bonnaud, Points de non-retour [Quais de Seine] [Points of no Return [Quais de Seine]] by Alexandra Badea, Blanche-Neige, Histoire d'un prince [Snow White, Story of a Prince] by Michel Raskin, were either wholly or in part produced by the Avignon Festival.

There was another reason for Love Triumphant remaining in the focus of attention, namely that it was written by the French director Olivier Py. It should be borne in mind that Py has been artistic director of the Avignon Festival for several years now. Ever since it was founded (1947), a personality or a group of personalities (Bernard Faivre d'Arcier being there the longest) has always been at the forefront of the festival, tasked with organising a summer theatre festival of a unique form and with a peculiar narrative that would reflect on theatrical and societal contexts. Initially, the role of the first chief compiler or of the "author" of the Avignon Festival was assumed by its founder, Jean Vilar. Currently, it is Olivier Py, which is a great honour and a token of trust for him. Rightly so: this director is currently among the most acclaimed ones, he has directed a number of brilliant productions and is also the director of Théâtre de l'Europe based in Odéon, Paris.

His production Love Triumphant was intended largely for younger audiences, but not only for them. Thanks to its poetics and aesthetic staging canon which draws on the history of French theatre, it has become a remarkable work even for a truly fastidious and experienced viewer. Love Triumphant is based on the story of the Grimm 


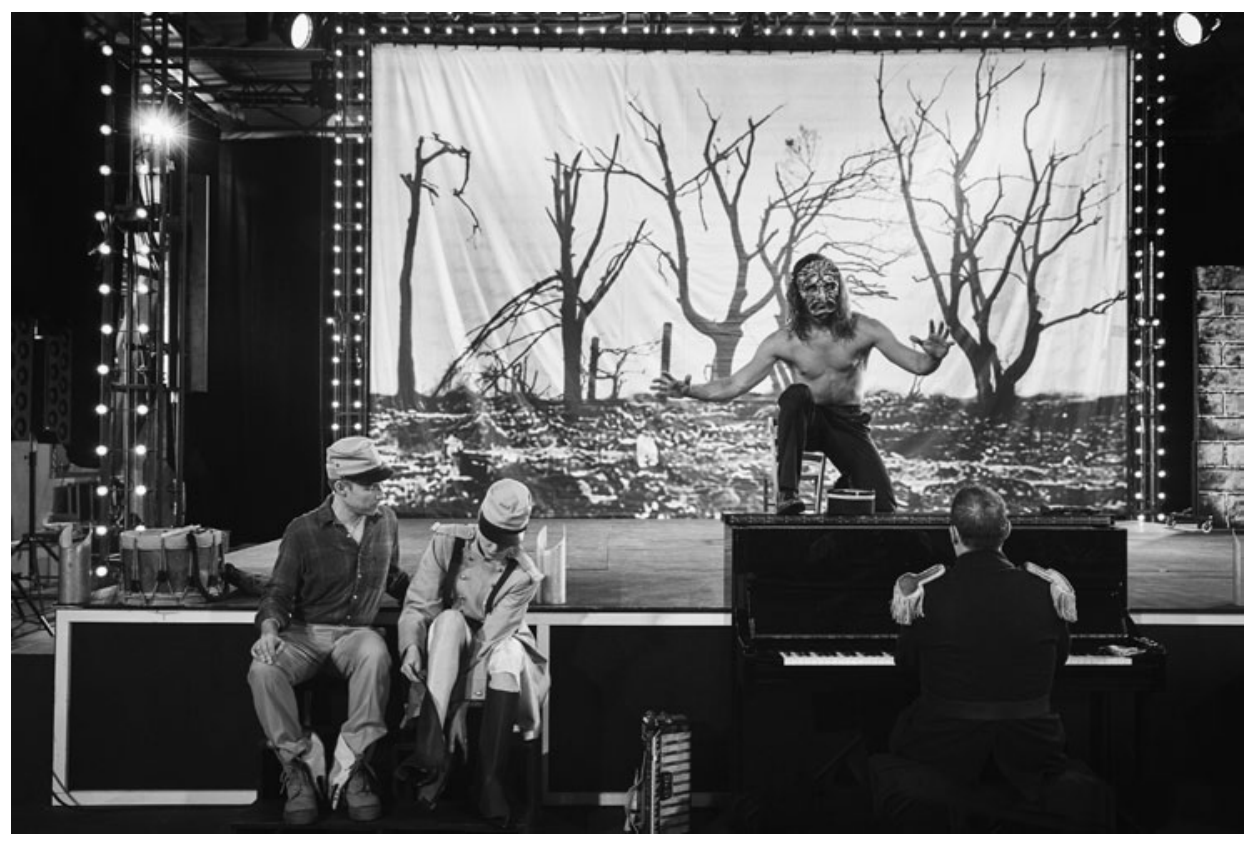

Love Triumphant. Text, direction and music Olivier Py. Stage design Pierre-André Weitz. Avignon 2019. Photo (C) Christophe Raynaud De Lage / Festival d'Avignon.

brothers. The princess who disobeyed her father and refused to marry the prince who was chosen for her, was locked up in a tower for seven years. The story unfolds when she finally gets out and goes looking for her true prince. But she is confronted with obstacles and with all the evil of the world. Evil is embodied mainly by the violent, destructive, dictatorial General. The princess sees how the world has changed for the worse and cannot get over it. Individual characters are unanchored, malcontent, coveting for a transformation of identity, they behave in an unnatural and egotistic way. The Princess and the Prince are confronted with the tricks of not only the General, but also of the Gardener, the kitchen maid, the washer-up.

Olivier Py based his staging on the Grimm brothers' fairy tale for the fourth time. In this case, he transcribed it into a classic alexandrine verse used by Pierre Corneille, Jean Racine, and Molière to create their masterpieces, and gave it the form of a musical comedy. The characters on the stage perform, sing songs, play musical instruments, they are versatile artists (Clémentine Bourgoin, Pierre Lebon, Flannan Obé, Antoni Sykopoulos). Initially, their exaggerated, voice-expressive acting and panoptical movement in this otherwise poetic-dramatic story was found distracting, until it became increasingly clear that Olivier Py, author of the text and music and stage director in one, maintained a pure style and a clear concept of the production. In it, in fact, a gentle reference is made to the tradition of Italian comedy and to the typical French guignol that was derived from it - it is a picturesque market puppet theatre, folk, dynamic, straightforward, and provocative. The production stage design alluded to this simple puppet theatre. The actors are kind of framed in it, and rapid transformations take place before the viewers by moving lightweight curtains 


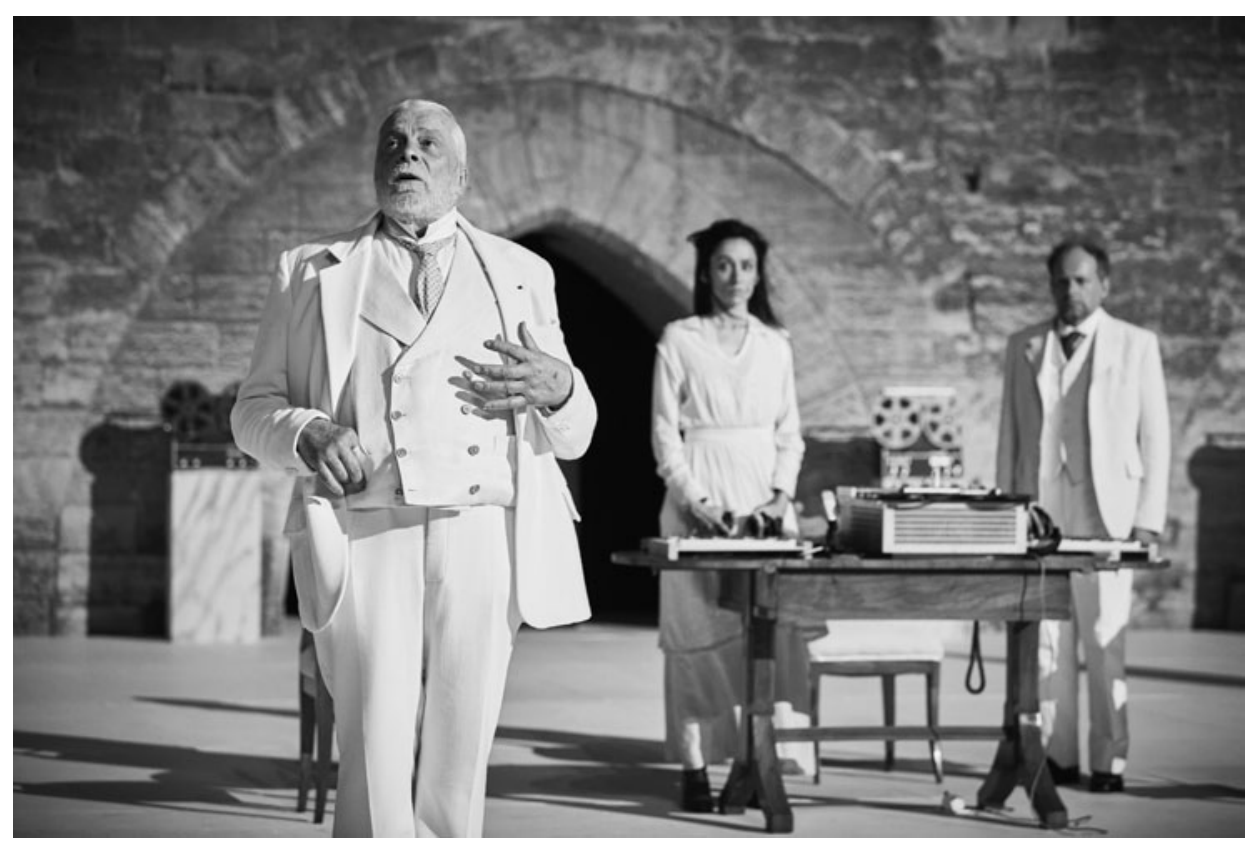

Architecture. Text, direction and installation Pascal Rambert. Paris - Avignon, 2019. Photo @ Christophe Raynaud De Lage / Festival d'Avignon.

and coverings in otherwise an almost empty space. In the foreground, there is a piano under the stage, with actors-musicians taking turns, standing with their backs to the audiences.

Thanks to a firm guidance and a clearly defined style, everything was interconnected and the stage director managed to artistically unite alexandrine, the German fairy tale, Italian comedy, and French guignol into a single form. It is an ambitious project worthy of Olivier Py's name, it is a funny and very entertaining piece, instructive for both children and adults (when it comes to adults, they outnumbered the children attending the performance).

Of the productions staged as festival productions, the dominant three-hour Architecture by Pascal Rambert, author and stage director in one, was presented in the central festival space - in an open amphitheatre for 2,000 spectators, in the courtyard of the Palace of the Popes. Rambert is one of the prominent personalities of contemporary French theatre, he is a playwright and writer, stage director, and has been a long-time director of the Théâtre de Gennevilliers. His intention for this year's Avignon edition was clear and legible. He ventured to create a monumental, thoughtful, serious, and formally ambitious work worthy of the festival and of the venue, the palace where it was performed. In Architecture, he portrays the saga of a big Viennese family at a time following the assassination in Sarajevo and the outbreak of World War I, to the Anschluss (annexation) of Austria by Nazi Germany on the eve of World War II. The Viennese family is exceptionally cultured, starting off with a patriarchal father, an outstanding architect, through his children and relatives who are masters of various arts and experts in scientific disciplines. Of course, entering into argu- 
ments with each other is unavoidable, just as is with the head of the family, the father, who is unable to keep abreast of the rapidly changing world of the $20^{\text {th }}$ century and he finds himself especially distanced from his youngest son who, from his standpoint, has a depraved mind and is mentally immature.

Rambert invited first-class French actors, led by Jacque Weber ${ }^{1}$, to enhance the artistic narrative of the performance. Among other performers were Emmanuelle Béart, Audrey Bonnet, Marie-Sophie Ferdane, Marina Hands, Arthur Nauzyciel, Stanislas Nordey, Denis Podalydès, Pascal Rénéric, and Laurent Poitrenaux who have engagements with Comédie-Française or with other reputable theatres. Thus, the performance was a showcase of the very best of French theatre communicating a powerful message in which Rambert posed a fundamental question: How can it be that such an advanced community of people, so knowledgeable and cultured, is prone to gradually succumb to dictators and to fail to avert war and Nazism? After all, historical development of which they are both a component part and actors, devours and destroys them physically, they die as a consequence of it.

Rambert tabled a weighty theme and verbalised brilliant thoughts through the mouths of his protagonists. He stated that, inter alia, he wished to demonstrate "the inability of an advanced language to halt rising fascism. ${ }^{\prime 2}$ Even though it contains profound ideas, overall, the production is found cumbersome, it is simply a transposition of the text of the original created à la thèse onto the festival stage. Weighty thoughts are heard but they are poorly integrated in the natural images of men. Since the time of Classicism, French theatre has had a strong tradition in reflective staging practice based on declamatory acting, initially subordinated to the ideological intent and propositions the author wished to verbalise (although in this case, Rambert's basic proposition is no longer a sensational novelty). French theatre has also developed a tradition of live, expressive, humanly spontaneous, and witty theatre which, regrettably, has circumvented Rambert's production. The monumental simple stage in the Palace of the Popes was rejected by the director and the stage designer, leaving only actors in white costumes and pieces of furniture on the white floor that were gradually replaced to match the $20^{\text {th }}$ century arts and crafts style development. In such a purely and emotionally aseptic universe, actors looked noble, their verbose monologues only corroborated that ideas came first, ordinary life followed suit.

The third major co-production title, this time mainly funded from Brussels-Brazilian sources, was the global project by Brazilian director Christiane Jatahy entitled O Agora que demora, Le présent qui déborde - Notre Odyssée II [The Lingering Now - Our Oddysey II]. It was about emigrants and immigrants, about a human or personal background of a big drama we have been witnessing in recent years, when people set

\footnotetext{
${ }^{1}$ In an interview, Jacques Weber says that despite his age, he has not performed in Avignon yet. He was attracted to Pascal Rambert who wrote a role for him. Otherwise, he has always seen the festival to be too commercial and disproportionately inflated. See further WEBER, J. - SALINO, B. «Les plus grands acteurs s'amusent tout le temps.» [The greatest actors always have a good time, an interview]. In Le Monde, 7 July 2019, annex Aix Arles Avignon. [online]. [cit. 22 July 2019]. Available at: https://www.lemonde.fr/culture/article/2019/07/07/jacques-weber-a-avignon-les-plus-grands-acteurs-s-amusent-tout-le-temps_5486398_3246. html.

${ }^{2}$ FRANCK-DUMAS, E. "Architecture», Avignon en état d'emphase. ["Architecture", Avignon Challenge]. In Libération, 5 July 2019. [online]. [cit. 22 July 2019]. Available at: https://next.liberation.fr/culture/2019/07/05/architecture-avignon-en-etat-d-emphase_1738241.
} 


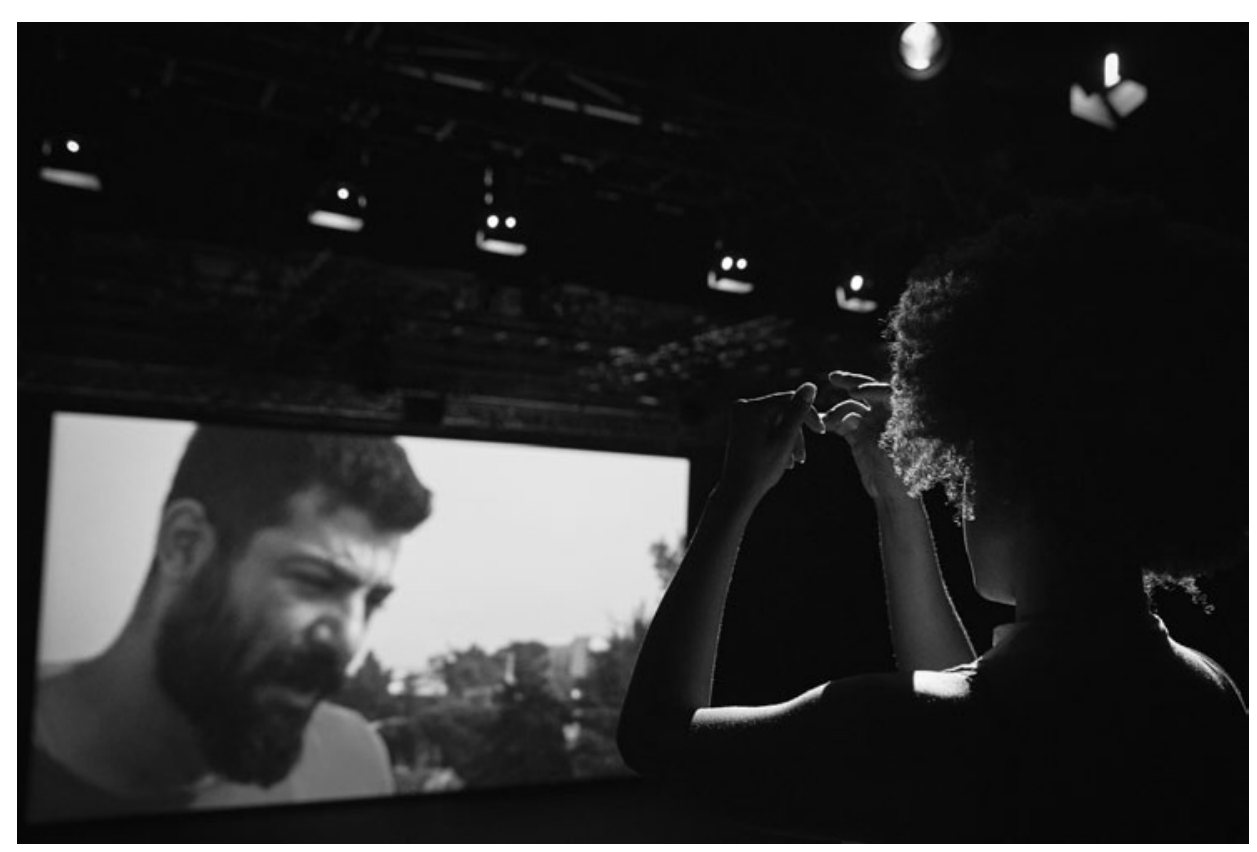

The Lingering Now - Our Oddysey II. Based on Homer. Direction, film direction, dramaturgy Christiane Jatahy. Stage design Thomas Walgrave. Rio de Janeiro - Brussels, 2019. Photo $@$ Christophe Raynaud De Lage / Festival d'Avignon.

off on a journey to more affluent and peaceful countries because of a disastrous situation back home. The female director Jatahy boasts a truly global perspective, which has helped her find many common features across different regions of the world: Palestine and Lebanon, Greece, South Africa, and finally at home, Brazil. She has travelled with her motion camera to all those countries, to shoot original testimonies and to bring back actors to share their personal fates with the audience.

It is far from being a cheap or poignant production. Jatahy sets the theme in her long-term project of the staging of Homer's Odyssey in three sequels. In this second part, she does not, as one might expect, probe into the causes of migration, nor does she address hostility toward migrants, their movement and trails, but rather surprisingly she discovers the state of their stillness. People from the third world are on the run but, as the production states, they will not get anywhere. The director knows their lives at close range and she states that "they have nowhere to stay, nowhere to go, or nowhere to return. ${ }^{\text {"3 }}$ By declaiming quotations from Homer's epic, she confronts the ancient Ulysses' ten-year journey with the factual stillness of contemporary migrants.

The production includes film material, but the shots of the everyday life in the migrants' countries of origin where residents are exposed to threats from nearby guard towers, serve only as a backdrop for authentic narration of persecuted people. That is

${ }^{3}$ JATAHY, Ch. - RAYES, Ch. Homère patrie [Homer's Homeland, an interview]. In Libération, 2 July 2019. [online]. [cit. 22 July 2019]. Available at: https://next.liberation.fr/theatre/2019/07/02/christiane-jatahyhomere-patrie_1737548. 


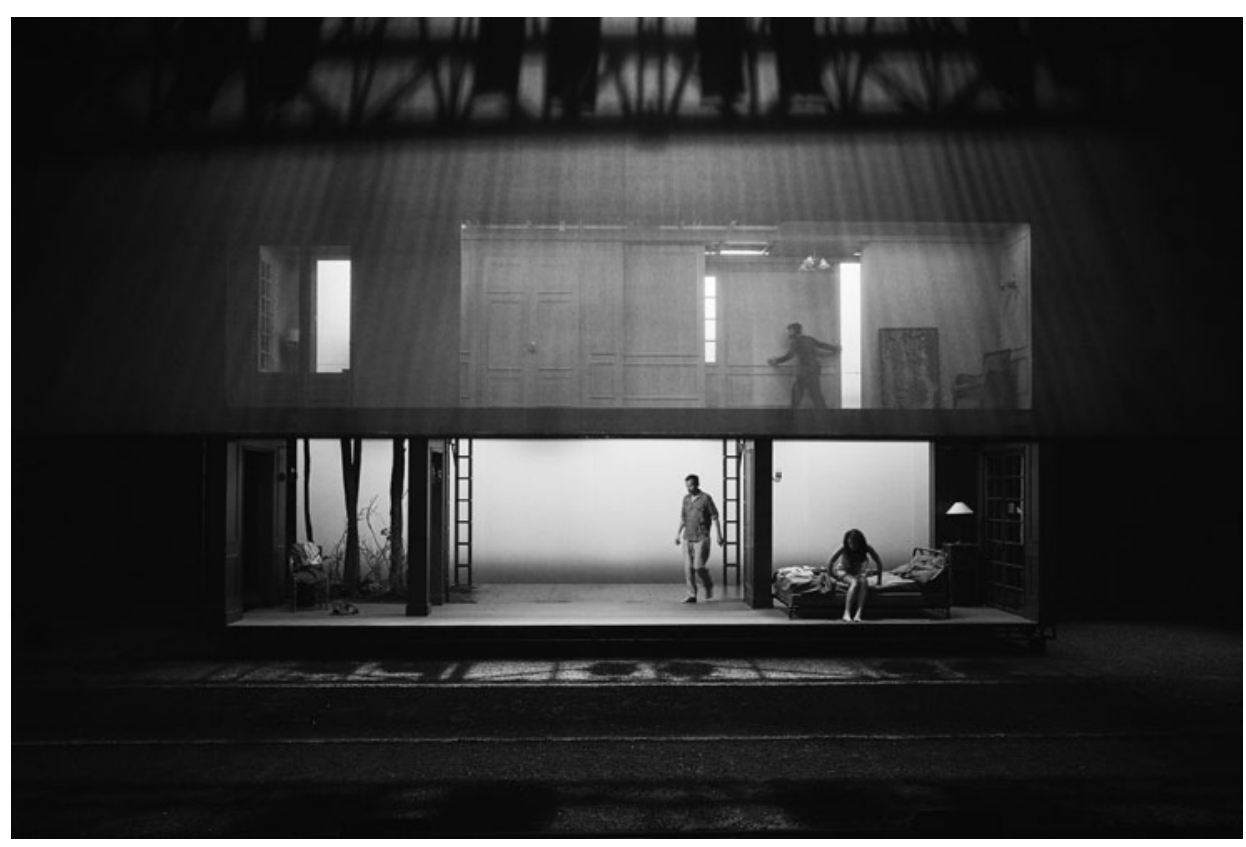

Maurice Maeterlinck: Pelléas and Mélisande. Direction Julie Duclos. Stage design Hélène Jourdan. Paris, 2019. Photo (C) Christophe Raynaud De Lage / Festival d'Avignon.

why the director eliminates the empty space between the stage and the auditorium. All the playing, dancing, and singing takes place not only on stage but also amidst the audiences. The director wished the viewers in Avignon to share the characters' fates for a while at least, to be able to understand them. Brazil, the director's homeland, is currently ruled by a president with whom she gets into an argument and she rejects him sharply because he is a right-wing populist and impedes migration. That is why she took her motion camera to the Brazilian rainforest, to meet the Indians affected by civilisation and who feel happy and free there, unaware of the fact that the scale of the rainforest they live in is constantly shrinking like a loop around them. It is a political theatre, which is not particularly committed or struggling, but - to use a more appropriate word - it is authentic and its strength lies in a true, honest, immediate testimony. Libération daily, in its special July edition covering the Avignon Festival, headlined its coverage Avignon La morale des troupes [Avignon, the Ethics of Theatre Companies]. ${ }^{4}$ It points out that the festival featured several performances such as this one, whereby the coverage dedicated most of its space to this particular one: "The festival's seventy-third edition yearns more than ever to speak on behalf of contemporary human epics and suppressed liberties. ${ }^{.5}$

Most of the authors of project-based productions opted for high-priority themes. One can say that they were committed productions, and the conditions to be met when applying for assistance underscored the need to seek answers to the world's current

\footnotetext{
${ }^{4}$ See Libération, Vol. 46, Issue 2742, p. I. (annex), 3 July 2019.

${ }^{5}$ Ibid.
} 


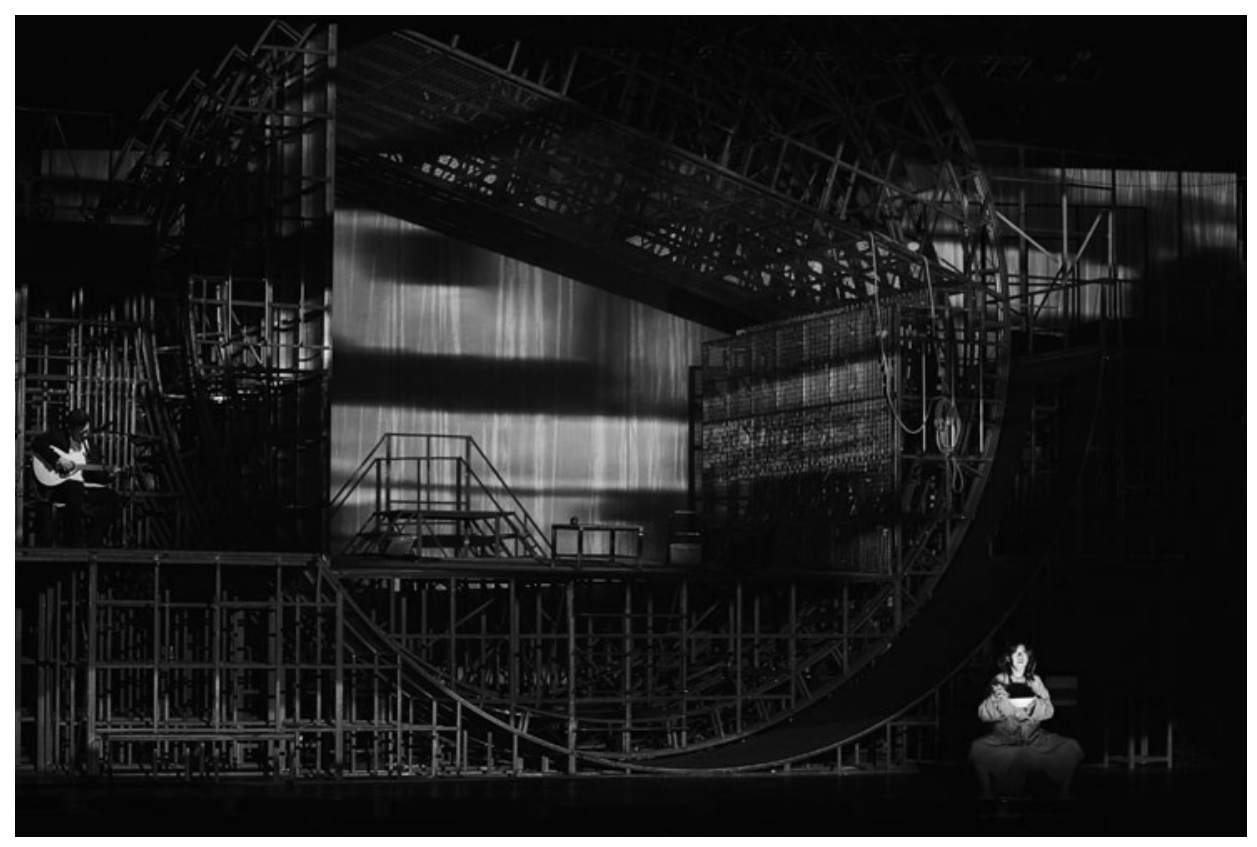

Lao She: The Teahouse. Direction, adaptation Meng Jinghui. Scenography Zhang Wu. Beijing, 2019. Photo (C) Christophe Raynaud De Lage / Festival d'Avignon.

problems. Therefore, in the programme (the official "IN", not the "OFF" one!) one would have hard time finding light comedies or distant art experimenting, let alone in the production of the symbolistic play Pelléas et Mélisande [Pelléas and Mélisande] by Maurice Maeterlinck, which has the potential to keep a metaphorical distance from reality and from the common themes of the chaotic world. The young director Julie Duclos, known to the public for her directions of experiments in improvisation theatre, presented a multimedia composition of a theatre connected with film screenings. She spatially arranged the actors into a two-storey stage construction that prevented their bodies and hands from moving freely and rendered it impossible to experience the joy of improvisation in the play. Philippe Chevilley, who otherwise wrote positively of the director, stated the following at the end of his review in Les Échos: "This play brings problems. The director who has always enchanted us with her natural and spontaneous way of leading the actors, has fallen into the trap of academism. The actions of the characters who are needlessly distant from each other are too formal. Julie Duclos does not find the right expressions for her efforts to connect the earth with the stars, the abstract with the concrete, to show an eroded world beyond love drama." ${ }^{\prime 6}$

Festival productions brought to the fore yet another piece of generalising know-

${ }^{6}$ CHEVILLEY, P. Avignon 2019: «Pelléas et Mélisande» en un rêve inabouti. [Pelléas and Mélisande in An Incomplete Dream]. In Les Échos, 6 July 2019. [online]. [cit. 22 July 2019]. Available at: https:// weekend.lesechos.fr/culture/spectacles/0601539062017-avignon-2019-pelleas-et-melisande-en-un-reveinabouti-2278887.php. 


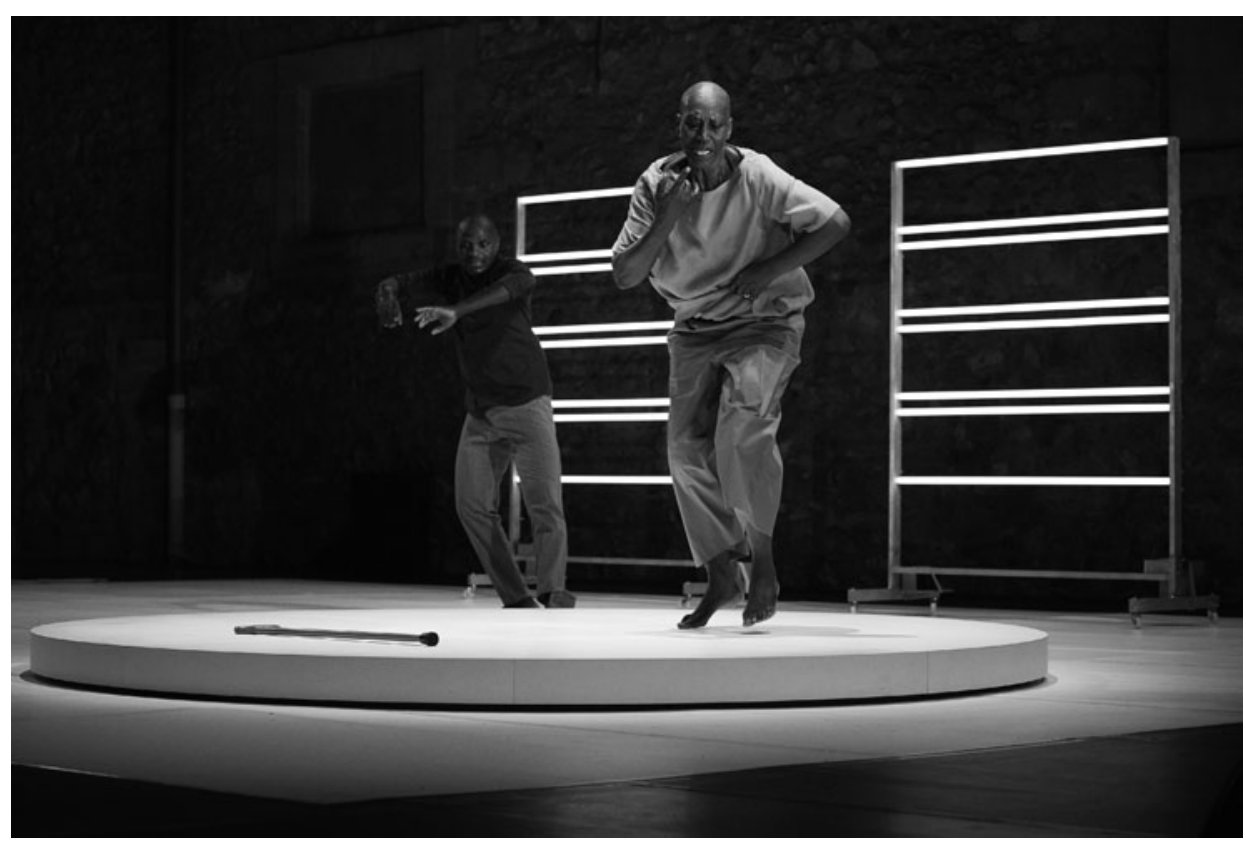

Multiple-s. From you to me, from many to you, and you'll be there. Conception and choreography Salia Sanou. Stage design Mathieu Lorry-Dupuy. Ouagadougou - Montpellier, 2019. Photo @ Christophe Raynaud De Lage / Festival d'Avignon.

ledge which has also been observed at other similar events, such as the Europe Theatre Prize, namely, a demand for outstanding personalities. In the late $20^{\text {th }}$ century, we boasted brilliant and widely recognised leading personalities on the international scene (Peter Brook, Giorgio Strehler, Peter Zadek, Peter Stein, Ariane Mnouchkine, Pina Bausch, Yuri Lyubimov, Antoine Vitez, Jacques Lassalle), of course, not all of them have performed in Avignon. Today, such personalities are scarce. Theatres have many prominent artists, but they rarely seem to have won such diverse recognition and their work has hardly had such an inspirational impact as that of their predecessors. One could also ask whether they achieve any such significant results. This is probably related not only to the way in which the theatre is funded, which has already been touched upon, but also to socio-cultural changes, the increase in quantity, the relativisation of values, the multipolarity not only of the world and of the Internet, but also of the theatre.

Let us not call into question the directors and actors who performed in Avignon. However, some productions that had been very well presented ahead of time, delivered a surprisingly controversial outcome. One such production was the mounting of an older play by the Chinese author Lao She La Maison de thé [The Teahouse], from 1956. A historical fresco in three parts portrays the period around 1898 and the downfall of the Empire, followed by a period after 1920, when Chiang Kai-shek reunited China, and finally after World War II, when the civil war broke out ending in a Communist victory in 1949. 
The stage director Meng Jinghui captured the epic time-lapse of fifty years in great style. A huge iron construction having the shape of a spherical sector with platforms fill the entire stage space and sometimes it moves. There are about 60 actors on the stage, playing with such an ecstatic enthusiasm that their faces and powerful voices will be engraved for long in memory. The director enjoys a unique position in China's contemporary theatre, he runs two theatres and shoots films. He is referred to as an avant-garde stage director and he also stages European drama (Samuel Beckett, Dario Fo, Eugène Ionesco). He studied in Beijing and was inspired by Chinese symbolic theatre of masks. The production The Teahouse is also suggestive of the constructivism of the Russian avant-garde post-revolution ensembles. The actors, through meticulous and clear-cut rendition, portray the action and characters of individual protagonists who had to defy the dramatic transformations of time and to struggle with all forms of love, hatred, and violence that the ordinary people of no importance were exposed to in China.

As was rightly pointed out by Libération daily, it is about an attitude. From what could be seen at the festival, the attitude, not an aesthetic perfection, but rather the cause, the purpose for which the production was created, deserves appreciation. This is also true of the less-known personalities or troupes, such as Germaine Acogny, Salia Sanou or Babx (David Babin), authors of a movement creation Multiple-s from Burkina Faso, dancers who strived to find a new definition of man, to search for their true selves in contact with archetypes and with other people who can multiplicate us. The director Jean-Pierre Vincent was invited to the festival with the production L'Orestie [Oresteia]. This time, he rehearsed it with his students from the school at the Théâtre National de Strasbourg. He made a rather challenging connection between young theatre, imperfect at times, and the oldest theatre classics, which is perfect and proven by history. Thus, he has highlighted two poles - and this year's edition of the Avignon Festival oscillated between them - outstanding, almost inaccessible peaks of human genius (in Homer, Architecture, Maeterlinck) stand in contrast with the conflicting and troubled times in which the endangered humanity is found. JeanPierre Vincent sums it up: "It is possible to mix beauty, wisdom, violence, and nonviolence...: all of that which makes it possible to keep talking about humanness, although for several reasons we must view the future of humanness in a pessimistic light. That is why I find it quintessential to go back to that what was in the early days of our civilisation." 7

The study is an output of SRDA project No. 15-0764, Slovak Theatre and Contemporary European Theatre Culture - Continuity and Discontinuity.

Translated by Mária Švecová

${ }^{7}$ VINCENT, J.-P. - PLOTAT SOLEYMAT, M. L'Orestie [Oresteia, an interview]. In La Terrasse, 23 June 2019. [online]. [cit. 22 July 2019]. Available at: https://www.journal-laterrasse.fr/lorestie-deschyle-mis-enscene-par-jean-pierre-vincent/. 


\section{LITERATURE}

FRANCK-DUMAS, Elisabeth. "Architecture», Avignon en état d'emphase. ["Architecture", Avignon Challenge]. In Libération, 5 July 2019. [online]. [cit. 22 July 2019]. Available at: https:// next.liberation.fr/culture/2019/07/05/architecture-avignon-en-etat-d-emphase_1738241. ISSN 0335-1793.

CHEVILLEY, Philippe. Avignon 2019: «Pelléas et Mélisande» en un rêve inabouti. [Pelléas and Mélisande in An Incomplete Dream]. In Les Échos, 6 July 2019. [online]. [cit. 22 July 2019]. Available at: https://weekend.lesechos.fr/culture/spectacles/0601539062017-avignon-2019-pelleas-et-melisande-en-un-reve-inabouti-2278887.php. ISSN 0153-4831.

JATAHY, Christiane - RAYES, Chantal. Homère patrie [Homer's Homeland, an interview]. In Libération, 2 July 2019. [online]. [cit. 22 July 2019]. Available at: https://next.liberation.fr/theatre/2019/07/02/christiane-jatahy-homere-patrie_1737548. ISSN 0335-1793.

Libération, Vol. 46, Issue 2742, p. I. (annex), 3 July 2019. ISSN 0335-1793.

VINCENT, Jean-Pierre - PLOTAT SOLEYMAT, Manuel. L'Orestie [Oresteia, an interview]. In La Terrasse, 23 Jun 2019. [online]. [cit. 22 July 2019]. Available at: https://www.journal-laterrasse.fr/lorestie-deschyle-mis-en-scene-par-jean-pierre-vincent/. ISSN 1241-5715.

WEBER, Jacques - SALINO, Brigitte. «Les plus grands acteurs s'amusent tout le temps.» [The greatest actors always have a good time, an interview]. In Le Monde, 7 July 2019, annex Aix Arles Avignon. [online]. [cit. 22 July 2019]. Available at: https://www.lemonde.fr/culture/ article/2019/07/07/jacques-weber-a-avignon-les-plus-grands-acteurs-s-amusent-tout-le-temps_5486398_3246.html. ISSN 1950-6244.

Miloš Mistrík

Ústav divadelnej a filmovej vedy CVU SAV

Dúbravská cesta 9

84101 Bratislava

Slovakia

e-mail: milos.mistrik@savba.sk 